Tiffani Howell ORCID iD: 0000-0002-4932-5792

\title{
When Zoo Visitors 'Connect' With a Zoo Animal, What Does That Mean?
}

\author{
Tiffani Howell $^{1,2} *$, Emily M McLeod ${ }^{1,3}$, and Grahame Coleman ${ }^{1}$
}

Running title: Meaning of connections with zoo animals

${ }^{1}$ Animal Welfare Science Centre, Faculty of Veterinary and Agricultural Sciences, 21 Bedford St, Level 2. The University of Melbourne, North Melbourne, 3051, Australia

${ }^{2}$ Current address: Anthrozoology Research Group, School of Psychology and Public Health, La Trobe University, Bendigo, VIC, 3552, Australia

${ }^{3}$ Current address: Department of Wildlife Conservation and Science, Zoos Victoria, Parkville, 3052, Australia

*Correspondence: t.howell@latrobe.edu.au; Tel.: +61-3-5444-7460

Ethics statement: This study received ethics approval from the University of Melbourne Human Research Ethics Committee (approval number 1647832.1).

\begin{abstract}
Connection with a zoo animal may increase conservation-mindedness in zoo visitors, potentially resulting in conservation-oriented behavior change. No research has attempted to establish what this 'connection' actually means. Visitors $(N=85)$ to Melbourne Zoo were asked to name the animal with which they most connected, the extent to which they connected with it, and to qualitatively describe what it meant to connect with that animal. Many (but not all) participants connected with charismatic megafauna: primate, great ape, large carnivore, or large herbivore. Qualitative This is the author manuscript accepted for publication and undergone full peer review but has not been through the copyediting, typesetting, pagination and proofreading process, which may lead to differences between this version and the Version of Record. Please cite this article as doi: 10.1002/zoo.21509.
\end{abstract}

This article is protected by copyright. All rights reserved. 
analysis revealed five common themes in the meaning of connection: Appreciation, Attribution, Inspires Emotions, Interaction, and Proximity. Overall connection level was significantly correlated with perceptions of conservation caring for the chosen species. Future research should aim to determine what factors affect a zoo visitor's connection level, which could impact attitudes and behaviors toward conservation.

\section{Highlights}

Zoo visitors indicated the animal they most connected with

Visitors also described what the connection meant for them, using free-text

Common themes: appreciation, attribution, inspires emotions, interaction, proximity

Keywords: conservation, empathy, interaction, appreciation, charismatic species When Zoo Visitors 'Connect’ With a Zoo Animal, What Does That Mean?

\section{Introduction}

Increasing conservation-mindedness and conservation-related behaviors in the general public is a key aim of zoological parks around the world (Barongi, Fisken, Parker, \& Gusset, 2015). It can be challenging to effect long-term behavior change in zoo visitors (Hughes, 2013; Smith, Broad, \& Weiler, 2008), although some studies do show a long-term impact on behavior change as reported by participants (Hughes, Packer, \& Ballantyne, 2011; Kemmerly \& Macfarlane, 2009; MacDonald, 2015). The reason for these conflicting results is not immediately clear, and it may be that particular experiences or aspects of a zoo visit are more likely to leave a lasting impact on an individual, which ultimately results in long-term behavior change. It could also be that self-reported behavior change may not reflect actual change.

This article is protected by copyright. All rights reserved. 
Research has identified several factors that may impact on whether zoo visitors are motivated to make positive behavioral changes after a zoo experience, much of which is based on the assumption that changes in their objective knowledge and attitudes towards conservation will result in behavioral changes. Mann-Lang and colleagues (2016) showed that the experience at the venue can have an effect on attitudes and knowledge: a presentation focused on educating participants about dolphins improved conservation attitudes and knowledge more than a theatre-style presentation aimed at entertaining the guests (Mann-Lang, Ballantyne, \& Packer, 2016) While attitudes may predict behaviour change (Ajzen, 1991), it is unclear whether behaviour change occurred in this instance. However, visitors who are given access to resources after their visit are more likely to report long-term behavior changes (e.g. picking up litter three months after the visit) than individuals who are not given such access (Hughes, 2011).

Zoos may also impact conservation-related behaviors in their visitors by manipulating how connected they feel with elements of the natural environment. Connectedness as a concept is not well-defined in existing scientific literature, with many researchers using many different descriptors to explain the phenomenon (Townsend \& McWhirter, 2005). Nonetheless, there is a strong relationship between a feeling of 'oneness' with another and empathic concern for them. This oneness also strongly predicts willingness to help (Cialdini, Brown, Lewis, Luce, \& Neuberg, 1997), something which many zoos aim to foster in their visitors in order to achieve their conservation objectives.

There is a growing body of literature in relation to how people connect with nature (see Restall \& Conrad, 2015, p. for reviews; Zylstra, Knight, Esler, \& Le 
Grange, 2014), including the development of various instruments that measure the human-nature relationship such as the Environmental Identity Scale (Clayton, 2003), the Inclusion of Nature in Self scale (Schultz, 2002), and the Nature Relatedness Scale (Nisbet, Zelenski, \& Murphy, 2009). Schultz (2002) describes this humannature relationship as characterized by three dimensions: i) the cognitive aspect that refers to the extent to which an individual's mental representation of self overlaps with their representation of nature; ii) the affective aspect, that refers to the extent to which an individual feels a sense of intimacy or emotional bond with nature; and iii) the behavioral aspect, that refers to an individual's commitment and motivation to act in the interests of nature.

Ives et al. (2018) developed this concept further by describing five dimensions of human-nature connectedness: material, experiential, cognitive, emotion, and philosophical. They argued that strengthening connections in these dimensions can help create a shift towards more sustainable behaviors and practices. Indeed, some studies suggest that feeling a connection with nature increases pro-environmental attitudes and behavior (Davis, Green, \& Reed, 2009; Hinds \& Sparks, 2008), although this relationship has not been borne out in all studies of this kind (Beery \& WolfWatz, 2014).

Zoo experiences appear to be one way to increase an individual's connection with nature (Bruni, Fraser, \& Schultz, 2008; Schultz \& Tabanico, 2007). Bruni et al (2008) surveyed zoo visitors entering and leaving three different zoos to investigate whether their visit increased their implicit and explicit connection with nature. Implicit connections were measured by an implicit association test aimed to identify unconscious perceptions, and explicit connections were measured by a survey aimed 
to identify conscious perceptions. While visitors showed no change in their explicit connection with nature, visitors leaving the zoo showed significantly higher implicit connections with nature than those entering the zoo. This was true for each zoo, regardless of whether they contained non-immersive but naturalistic exhibits, as found at two of the zoos, or more immersive exhibits, as found at the third zoo (Bruni et al., 2008). Additionally, by testing visitors multiple times during one zoo visit, Schultz and Tabanico (2007) found that their implicit connection to nature increased across the course of their visit. This suggests that the experiences a visitor has during their zoo visits helps them to form stronger connections to nature.

In addition to increasing connections with nature, zoos provide an opportunity for visitors to form a connection to the animals they view (Clayton, Fraser, \& Saunders, 2009). While not evidence of causation, Clayton et al (2014) found that people who were zoo members or frequent zoo visitors felt a stronger connection with animals than people who were not members or who visited the zoo less frequently. This stronger sense of connection to animals among visitors was associated with greater acceptance of the evidence indicating climate change and increased selfefficacy in reducing their impact on climate change (Clayton et al., 2014). Likewise, when Grajal et al (2016) surveyed over 3500 visitors to U.S zoos and aquariums, they found that sense of connection to animals predicted self-reported engagement in behaviors to address climate change. The finding that individuals who had stronger connections to animals were more likely to report performing pro-environmental behaviors, led the authors to suggest that animal exhibits and experiences should be designed to give visitors the chance to foster and reflect on their sense of connection to animals (Grajal et al., 2016). In another study of zoo visitors, Clayton et al (2011) found that an increased sense of connection to animals in a zoo was associated with 
increased desire to help animals in the zoo and the wild, suggesting that zoos may help foster an environmental identity and increase environmental concern amongst their visitors.

Skibins and Powell (2013) developed the Conservation Caring scale as a way to measure an individual's level of connection to a specific species. In their study of zoo visitors, they asked participants to nominate the species they formed the strongest connection with during their visit and examined how their level of connection, as measured by the Conservation Caring scale, related to their pro-environmental behavioral intentions (Skibins \& Powell, 2013). While only a weak predictor of general biodiversity orientated behaviors, a visitor's connection with a species was a strong predictor of their intent to engage in conservation-related behaviors to help conserve that particular species (Skibins \& Powell, 2013).

Just as the term 'connection' is poorly defined, there has been little empirical research examining what is meant by a 'connection' with an animal. Myers et al (2004) found visitors reported different levels of connection across three animal enclosures at Brookfield Zoo and expressed varying levels of positive emotions depending on the behavior of the animals they were observing. When visitors perceived that the animals were paying attention to them or other visitors, they reported higher levels of respect, peacefulness, amusement, surprise and a greater sense of connection (Myers et al 2004). Building on this research, Luebke (2018) found when zoo visitors were given the opportunity to highlight any "extra special" experiences during their visit, the most common responses focused on active animal behaviors or interactions/close encounters between the visitor and the animal. These experiences were strongly associated with visitors reporting greater connection with, 
and concern and empathy towards, the animals and wildlife in general (Luebke, 2018).

Another potentially special experience for visitors relates to the quality of the exhibit. When Skibins and Powell (2013) asked visitors to identify the species they most connected with, one of the five most commonly reported species was jellyfish. The researchers suggested that this somewhat surprising result may be a result of the jellyfish exhibit which incorporated advanced exhibit design and created a unique and immersive experience for the visitors, which may have fostered a connection with the species. Since it is likely that connection will mean different things to different people, it is possible that an individual's subjective experience of that connection, and how they define it, may impact their likelihood of engaging in conservation-related behaviors in the future. All of these issues should be disentangled, to better understand how and why connectedness with an animal might impact on conservation behaviors. To that end, this study aimed to examine which animal people most connected with during a visit to Melbourne Zoo, what that connection meant to them, and whether that connection was correlated with conservation-related attitudes or behavioral intentions.

\section{Method}

Visitors to Melbourne Zoo were approached at various locations within the zoo. People were approached through convenience sampling during non-peak periods. Only adults were approached, but sometimes they had children with them. Visitors who were unable to converse in English were excluded from the study. A greater proportion of women in the zoo during the recruitment periods resulted in more responses obtained from women. They were given leaflets explaining that, by 
completing a 10-minute online survey at home in their own time, they could enter a drawing for a free Close Encounter experience of their choosing (valued at \$30), in which a small group of people spends time 'behind the scenes' with an animal. The leaflet also contained the survey link, which participants used to access the web-based survey and enter the drawing. Data collection proceeded from September 2016 through January 2017, with a response rate of approximately $20 \%$.

\section{Research instrument}

Participants completed an online survey consisting of demographic items, as well as items related to general concern for wildlife conservation, adapted from Skibins and Powell (2013). As in Skibins and Powell, participants were asked to indicate which animal they formed the strongest connection with during their visit using an open-ended, free-text response. They were then asked to indicate the level of this connection on a scale from 1 (no connection at all) to 7 (extremely strong connection), and to use open-ended, free text to describe, in a sentence or two, what 'connection with an animal' meant to them. They were asked, using closed responses, how long they were at that animal's enclosure, their distance from the animal, how well they could see the animal, and to what extent the animal made visual contact with them and interacted (i.e. responded to the participant's presence or movements) with them. Participants were then asked to report their level of agreement with items related to their pro-conservation intent regarding that animal species, using Skibins and Powell's Conservation Caring scale and behavioral intent measures (Skibins \& Powell, 2013). The full survey is available as supplementary material.

This article is protected by copyright. All rights reserved. 


\section{Analysis}

Qualitative data from the item related to the meaning of a connection were analyzed using NVivo qualitative analysis software, version 11 (QSR International, Doncaster, Victoria, Australia), to assist in extracting common themes and patterns.

Quantitative data were analyzed with SPSS statistical package, version 20. In order to reduce the number of variables needed for analysis, reliability analyses were conducted on items that loaded on the same factors as those presented in Skibins and Powell (2013). These reliability analyses permitted a further validation of some of their factors, using data from this study. For items that were created for the current study, reliability analyses were performed on items that were conceptually similar to each other. Table 1 shows the conservation-related items that were combined by averaging into composite variables and their associated Cronbach's $\alpha$, as well as items that were retained for individual analysis. Individual items were retained for one of two reasons: either they were conceptually dissimilar to other items forming the composite variables, or the Cronbach's $\alpha$ levels were unacceptably low when they were included in the reliability analyses with other items during composite variable construction. Two items, 'I prefer to interact with domestic animals (e.g. cats and dogs) than to seek out wildlife opportunities', and 'I prefer other activities (e.g. watching movies; dining with friends) to watching wildlife’ were reverse-scored, such that a higher score indicated a greater preference for wildlife.

Participants were asked to write the animal with which they connected most during their visit, using open-ended free-text. These responses were grouped into animal categories when presenting descriptive results. Pearson's correlations were used to determine whether overall connection level correlated with proximity to the 
animal, and with the composite and individual conservation-related items provided in Table 1.

\section{Results}

\section{Participants}

A total of 85 visitors to Melbourne Zoo completed the online survey. Most participants (78.8\%) were female, and $70.1 \%$ were zoo members. The mean age was 42 years $(\mathrm{SD}=10.5$ years $)$. All participants lived in Australia.

\section{What animal types do visitors connect with?}

Participants' reports, of the animal to which they most connected during their visit were grouped into the following categories, for ease of interpretation: bird, butterfly, great ape, large carnivore, large herbivore, primate, reptile, small carnivore, and small herbivore. Table 2 shows the individual animal species represented within each category and the number of participants who indicated that they connected with that animal, along with means $(M)$ and standard deviations $(S D)$ for the connection level for each animal category. Even though Melbourne Zoo has over 320 species on site, visitors only listed 22 species, in nine categories, with which they connected. Among participants who reported that they connected with an animal, the connection level varied from $M=4.25(S D=1.50)$ for reptiles to $M=5.45(S D=1.04)$ for large carnivores.

\section{What 'connectedness' to a zoo animal means}

A wide range of participants' descriptions of what “connection” meant to them were recorded. A summary of the themes identified, and illustrative quotes are 
presented in Table 3. Since many quotes incorporated more than one theme, a secondary theme was identified in many cases. These themes were considered secondary generally because there was lesser emphasis on that theme. If the emphasis seemed equivalent for the two identified themes, the secondary theme was the theme mentioned later in the quote. The five most common primary themes extracted from the participants' meaning of connection were: appreciation of the animal (Appreciation), attribution of mental states to the animal (Attribution), inspires emotions in the visitor (Inspires Emotions), interaction with the animal (Interaction), and proximity to the animal (Proximity). Together they accounted for the connection meaning provided by 52 participants, or $61 \%$ of the total sample. However, other themes were also represented, including learning opportunities, the recognition of various traits in the animal, and affinity with the natural world. Finally, two participants indicated that they did not understand the question, including one of the two participants who had not named any animal when asked to indicate the animal they most connected with.

\section{Conservation attitudes/behavior, proximity, and connection level}

There were several significant relationships between some questionnaire items and the overall connection level with the animal identified by each participant. All significant relationships were weak to moderate; the strongest effect size was observed for a positive relationship between overall connection level and species-specific conservation caring (see Table 1 for description of this composite variable). The significant correlations were between connection level and three measures willingness to engage in conservation behaviors, as well as with Existing connection to wildlife, Species-specific conservation caring, Perceived welfare in enclosure, "I will endorse 
public policy that severely restricts future growth and development in order to protect wildlife”, "Wildlife protection must be society’s highest priority" and "I feel a sense of calm when I watch wildlife” (Table 4). There was no relationship between connection level and any of the items pertaining to proximity to, or interaction with, the animal. The significant results only are reported in Table 4.

\section{Discussion}

This study, which aimed to better characterize the relationship between connection with a zoo animal and conservation-related attitudes and behavioral intentions, appears to be the first to examine what people mean when they say they feel such a connection. Several themes were found in the qualitative responses that people provided, but the five most common were: Appreciation, Attribution, Inspires Emotion, Interaction, and Proximity. Participants were asked to rate the level of connection that they felt with an animal, and degree of connection was positively correlated with endorsement of several conservation-related items. The strongest of these were the composite variables species-specific conservation caring and existing connection to wildlife, and the individual item related to feeling calm when observing wildlife. Based on the results of this study, zoos should be looking to increase the connection that visitors feel with the animals they see when they are at the zoo, in order to meet their goal of inspiring conservation-mindedness in their visitors.

As anticipated, qualitative responses to the item asking participants to define what 'connection' meant to them, resulted in a large variety of themes. Many of the themes related to some enjoyment or appreciation of the animal, as well as a desire to have some sort of meaningful interaction. Also represented were the acknowledgement (or attribution) of human characteristics in the animal, which made 
the animal more relatable. A desire to protect the animal, or its environment, was noted by some participants; these individuals appeared to take a larger view of the individual animal beyond its life in the zoo, considering how humans can impact native habitats and the extent of our responsibility for protecting them. These themes could relate to the cognitive and affective components of connectedness with nature, as described by Schultz (2002).

Two of the themes, Attribution and Inspires Emotion, are conceptually similar to the two main facets of empathy. Attribution corresponds to mental state attribution, the first component of empathy (Lawrence, Shaw, Baker, Baron-Cohen, \& David, 2004). The theme Inspires Emotion relates closely to feeling the same emotions that the other is believed to be feeling (i.e. a vicarious experience of the animal's perceived emotions), which is the second component of empathy as reported in psychology literature (Lawrence et al., 2004).

The current study extended the work of Skibins and Powell (2013), who created the Conservation Caring scale, related to a zoo visitor's connection with an animal, and found that it was correlated with intended conservation-related behaviors related to that particular species. The current study included Skibins and Powell's Conservation Caring scale, but also asked individuals to rate their level of connection to the animal. The species-specific conservation caring composite variable in the current study, which heavily overlaps with, but is not identical to, Skibins and Powell's Conservation Caring scale, did correlate positively with the overall connection level. The existing connection to wildlife composite variable was also moderately correlated with connection level. The connection level correlated with several other conservation-related items, including a few individual items that related 
to general wildlife protection, such as a willingness to donate to conservation causes, and supporting public policies the restrict future growth in order to protect wildlife. This is different from the results of Skibins and Powell, who found that connection with an animal, as measured by their conservation caring scale, only weakly predicted general biodiversity conservation-related behaviors.

The composite variable related to perceived welfare in the animal's enclosure was correlated with connection level, albeit with a small effect size. This suggests that animal welfare concerns are sometimes a consideration in determining level of connection with an animal. A few of the qualitative responses indicated a concern for the animal's welfare in captivity, so there may be some individuals for whom welfare is particularly important, especially in terms of feeling a sense of empathy with the animal. This was noted most often for the great apes and primates, which accords previous research showing that people are most concerned about animal welfare for species which are ‘like us’ (Hagelin, Carlsson, \& Hau, 2003).

Beyond conservation caring, an interesting result of Skibins and Powell's (2013) study was the types of animals that visitors most connected with during their zoo visit. These connections were not exclusively formed with charismatic megafauna, that is, large, high-profile animals (often mammals) that are typically dominant in their natural environment (e.g. great apes, big cats, elephants, polar bears) (Walpole \& Leader-Williams, 2002). Zoos often consider these animals to be 'flagship’ species because of their perceived ability to influence visitors' emotions (Skibins \& Powell, 2013). Instead, one of the most commonly selected animals in the Skibins and Powell study was jellyfish, which the authors suppose was due to a highquality jellyfish exhibit at one of their study sites. Similarly, participants in the current 
study did not always choose charismatic species, but showed a large range of animals selected. Several of the animals were charismatic, such as great apes, large herbivores, and large carnivores, which accords with another recent study on connectedness with animals at the Melbourne Zoo (Skibins, Dunstan, \& Pahlow, 2017). However, a few participants indicated birds, butterflies or reptiles.

In the case of participants who reported connecting with the butterflies, this may be because the butterfly house at Melbourne zoo is a large space in which butterflies move freely around visitors, sometimes landing on them or flying very close to them. It is possible that this exhibit is of similar quality to the jellyfish exhibit in Skibins and Powell (2013), providing an immersive experience for visitors that may help to facilitate a connection with the butterflies. However, this has not yet been investigated empirically.

Previous research has shown that interactions with zoo animals had a positive impact on visitor connection levels and enjoyment of the zoo experience (Luebke, 2018; Myers Jr et al., 2004). Therefore, it was expected that the connection felt by some participants would relate to proximity or interaction with the animal, so participants were asked to describe the extent to which they could see or interact with it. This was asked after participants provided free-text responses describing the meaning of their connection, so that they would not be primed to provide this type of information in their descriptions. This expectation was realized in the themes embedded in the qualitative responses to the item asking participants what connection meant to them; two of the five most common themes were Interaction and Proximity. These items, paradoxically, did not correlate with the overall connection level. However, participants who defined connection in these ways did also rate higher on 
individual items in the survey asking about the extent of the human-animal interaction (e.g. how much the animal looked at or responded to the participant). Whether the interaction with the animal informed their definition of connection, or whether they specifically sought interactions with the animal because they were looking for a connection, is unclear.

For many of the participants in this sample, the interaction with an animal was not a physical interaction but rather "a sense of feeling that they sense you". This is consistent with earlier studies where zoo visitors who perceived that the animal was paying them or other visitors attention, reported a greater sense of connection, in addition to experiencing higher levels of positive emotions (Myers et al; Luebke 2018). These findings provide some interesting insights into how visitors may connect with animals in zoo settings. Understanding these common themes of connection may allow zoos to enhance or alter exhibits and experiences to help facilitate these connections. For instance, providing close-up viewing opportunities with animals whose welfare is not impacted by the presence of visitors (e.g. Bloomfield, Gillespie, Kerswell, Butler, \& Hemsworth, 2015; Sherwen, Magrath, Butler, Phillips, \& Hemsworth, 2014) may allow visitors a greater chance of perceiving a level of interaction with the animals and feeling a sense of connection.

Despite the novel results reported in this study, which provides more detailed insights into what people mean when they say they feel a connection to a zoo animal, a few limitations should be noted. In particular, the sample size was small and data collection was limited to just one zoo. In the future, it is recommended that a larger number of participants, from a variety of different zoo and aquarium settings, be included. Nonetheless, as aspects of the current study were qualitative, the sample 
size was appropriate for this particular method and allowed the identification of the common themes of what connection means to zoo visitors. Future research could adapt the themes presented in the qualitative results of the current study, for use in a larger, quantitative study.

Zoos around the world aim to increase conservation-related behaviors in their visitors (Barongi et al., 2015; Zoos Victoria, 2015), and there appears to be a relationship between the connection that a zoo visitor feels with an animal and conservation attitudes, as well as at least some conservation-related behavioral intentions. Future research should aim to identify the factors determining what might increase an individual's feeling of connectedness with zoo animals.

\section{Acknowledgements}

We thank two anonymous reviewers for their comments on a previous version of this manuscript. We appreciate the insights of the survey participants, who took the time to tell us about the animals they connected with and what that meant for them.

\section{References}

Adelman, L. M., Falk, J. H., \& James, S. (2000). Impact of National Aquarium in Baltimore on visitors' conservation attitudes, behavior, and knowledge. Curator: The Museum Journal, 43(1), 33-61.

Ajzen, I. (1991). The theory of planned behavior. Organizational behavior and human decision processes, 50(2), 179-211.

Barongi, R., Fisken, F. A., Parker, M., \& Gusset, M. (2015). Committing to Conservation: The World Zoo and Aquarium Conservation Strategy. Retrieved from Gland: http://www.waza.org/en/site/conservation/conservation-strategies

Beery, T. H., \& Wolf-Watz, D. (2014). Nature to place: Rethinking the environmental connectedness perspective. Journal of Environmental Psychology, 40, 198205.

This article is protected by copyright. All rights reserved. 
Bloomfield, R. C., Gillespie, G. R., Kerswell, K. J., Butler, K. L., \& Hemsworth, P. H. (2015). Effect of partial covering of the visitor viewing area window on positioning and orientation of zoo orangutans: A preference test. Zoo Biology, 34(3), 223-229.

Bruni, C. M., Fraser, J., \& Schultz, P. W. (2008). The value of zoo experiences for connecting people with nature. Visitor Studies, 11(2), 139-150.

Cialdini, R. B., Brown, S. L., Lewis, B. P., Luce, C., \& Neuberg, S. L. (1997). Reinterpreting the empathy-altruism relationship: When one into one equals oneness. Journal of Personality and Social Psychology, 73(3), 481.

Clayton, S. (2003). Environmental identity: A conceptual and an operational definition. In S. Clayton \& S. Opotow (Eds.), Identity and the natural environment: The psychological significance of nature (pp. 45-65). Cambridge, MA, USA: The MIT Press.

Clayton, S., Fraser, J., \& Burgess, C. (2011). The role of zoos in fostering environmental identity. Ecopsychology, 3(2), 87-96.

Clayton, S., Fraser, J., \& Saunders, C. D. (2009). Zoo experiences: Conversations, connections, and concern for animals. Zoo Biology, 28(5), 377-397.

Clayton, S., Luebke, J., Saunders, C., Matiasek, J., \& Grajal, A. (2014). Connecting to nature at the zoo: Implications for responding to climate change. Environmental Education Research, 20(4), 460-475.

Davis, J. L., Green, J. D., \& Reed, A. (2009). Interdependence with the environment: Commitment, interconnectedness, and environmental behavior. Journal of Environmental Psychology, 29(2), 173-180.

Falk, J. H., \& Adelman, L. M. (2003). Investigating the impact of prior knowledge and interest on aquarium visitor learning. Journal of Research in Science Teaching, 40(2), 163-176.

Grajal, A., Luebke, J., Clayton, S., Kelly, L., Karazsia, B., Saunders, C., \& Mann, M. (2016). The relationship between affective connections to animals and proenvironmental behaviors. Conservation biology, 31(2), 322-330.

Hagelin, J., Carlsson, H.-E., \& Hau, J. (2003). An overview of surveys on how people view animal experimentation: some factors that may influence the outcome. Public Understanding of Science, 12(1), 67-81. doi:10.1177/0963662503012001247

Hinds, J., \& Sparks, P. (2008). Engaging with the natural environment: The role of affective connection and identity. Journal of Environmental Psychology, 28(2), 109-120.

Hughes, K. (2011). Designing post-visit action resources for families visiting wildlife tourism sites. Visitor Studies, 14(1), 66-83.

This article is protected by copyright. All rights reserved. 
Hughes, K. (2013). Measuring the impact of viewing wildlife: Do positive intentions equate to long-term changes in conservation behaviour? Journal of Sustainable Tourism, 21(1), 42-59.

Hughes, K., Packer, J., \& Ballantyne, R. (2011). Using post-visit action resources to support family conservation learning following a wildlife tourism experience. Environmental Education Research, 17(3), 307-328.

Ives, C. D., Abson, D. J., von Wehrden, H., Dorninger, C., Klaniecki, K., \& Fischer, J. (2018). Reconnecting with nature for sustainability. Sustainability Science, 13(5), 1389-1397.

Kemmerly, J. D., \& Macfarlane, V. (2009). The elements of a consumer-based initiative in contributing to positive environmental change: Monterey Bay Aquarium's Seafood Watch program. Zoo Biology, 28(5), 398-411.

Lawrence, E. J., Shaw, P., Baker, D., Baron-Cohen, S., \& David, A. S. (2004). Measuring empathy: Eeliability and validity of the Empathy Quotient. Psychological Medicine, 34(05), 911-920.

Luebke, J. F. (2018). Zoo exhibit experiences and visitors' affective reactions: A preliminary study. Curator: The Museum Journal, 61(2), 345-352.

MacDonald, E. (2015). Quantifying the impact of Wellington Zoo's persuasive communication campaign on post-visit behavior. Zoo Biology, 34(2), 163169.

Mann-Lang, J, Ballantyne, R., \& Packer, J. (20 16). Does more education mean less fun? A comparison of two animal presentations. International Zoo Yearbook, 50(1), 155-164.

Myers Jr, O. E., Saunders, C. D., \& Birjulin, A. A. (2004). Emotional dimensions of watching zoo animals: An experience sampling study building on insights from psychology. Curator: The Museum Journal, 47(3), 299-321.

Nisbet, E. K., Zelenski, J. M., \& Murphy, S. A. (2009). The nature relatedness scale: Linking individuals' connection with nature to environmental concern and behavior. Environment and Behavior, 41(5), 715-740.

Restall, B., \& Conrad, E. (2015). A literature review of connectedness to nature and its potential for environmental management. Journal of Environmental Management, 159, 264-278.

Schultz, P. W. (2002). Inclusion with nature: The psychology of human-nature relations Psychology of Sustainable Development (pp. 61-78): Springer.

Schultz, P. W., \& Tabanico, J. (2007). Self, Identity, and the Natural Environment: Exploring Implicit Connections With Nature 1. Journal of Applied Social Psychology, 37(6), 1219-1247.

This article is protected by copyright. All rights reserved. 
Sherwen, S. L., Magrath, M. J., Butler, K. L., Phillips, C. J., \& Hemsworth, P. H. (2014). A multi-enclosure study investigating the behavioural response of meerkats to zoo visitors. Applied Animal Behaviour Science, 156, 70-77.

Skibins, J. C., Dunstan, E., \& Pahlow, K. (2017). Exploring the influence of charismatic characteristics on flagship outcomes in zoo visitors. Human Dimensions of Wildlife, 1-15.

Skibins, J. C., \& Powell, R. B. (2013). Conservation caring: Measuring the influence of zoo visitors' connection to wildlife on pro-conservation behaviors. Zoo Biology, 32(5), 528-540.

Smith, L., Broad, S., \& Weiler, B. (2008). A closer examination of the impact of zoo visits on visitor behaviour. Journal of Sustainable Tourism, 16(5), 544-562.

Townsend, K. C., \& McWhirter, B. T. (2005). Connectedness: A review of the literature with implications for counseling, assessment, and research. Journal of Counseling \& Development, 83(2), 191-201.

Walpole, M. J., \& Leader-Williams, N. (2002). Tourism and flagship species in conservation. Biodiversity \& Conservation, 11(3), 543-547.

Zoos Victoria. (2015). 2015-20 Community Conservation Master Plan. Retrieved from Melbourne, VIC: https://www.zoo.org.au/news/zoos-victoria-launchescommunity-conservation-master-plan

Zylstra, M. J., Knight, A. T., Esler, K. J., \& Le Grange, L. L. (2014). Connectedness as a core conservation concern: An interdisciplinary review of theory and a call for practice. Springer Science Reviews, 2(1-2), 119-143.

This article is protected by copyright. All rights reserved. 
Table 1: Items included in composite variables created for analysis, and items that were analysed individually. All individual items were scored on a scale from 1 (strongly disagree) to 7 (strongly agree)

\section{Composite Items included variable name}

Existing connection to wildlife

I actively seek opportunities to view wildlife

I feel a deep connection to wildlife

I am highly motivated by the need to interact with wildlife

I spend a lot of time learning about wildlife

Speciesspecific conservation caring

Perceived welfare in enclosure
Ensuring this species’ survival is my highest priority

My emotional sense of well-being will be severely diminished by the extinction of this species

I need to learn everything I can about this species

I would protest Zoos Victoria if I learned of the mistreatment of this animal

I will alter my lifestyle to help protect this species

My connection to this animal has increased my connection to the species as a whole

I will learn more about this species in general (e.g., behavior, natural habitat)

I will learn more about steps I can take to help protect this species

I would purchase an item from the Melbourne Zoo gift shop that supports the conservation of this species

There is ample space in this animal's enclosure to allow social interaction as well as alone time for individuals if they choose

This animal's enclosure design and features provide for a range of species appropriate behaviors

This animal looked content in its enclosure 


\section{Items analysed individually}

I will endorse public policy that severely restricts future growth and development in order to protect wildlife

Government officials’ views on wildlife are a major factor in my voting decisions

Even when they are more expensive or harder to find, I will buy groceries and products that support wildlife conservation

Wildlife protection must be society's highest priority

I enjoy watching wildlife

I feel a sense of calm when I watch wildlife

I prefer to interact with domestic animals (e.g. cats and dogs) than to seek out wildlife viewing opportunities (reverse-scored)

I prefer other activities (e.g. watching movies; dining with friends) to watching wildlife (reverse-scored)

Table 2: Categories of animal types, the animal species included in each category, and the total number $(N)$, number of males and females, and percentage of participants who named each animal. Means (M) and standard deviations (SD) are also presented for the level of connection reported by participants who connected with each category, on a scale of 1 (no connection at all) to 7 (extremely strong connection).

\begin{tabular}{|c|c|c|c|c|c|c|c|}
\hline \multirow[t]{2}{*}{$\begin{array}{l}\text { Animal } \\
\text { type }\end{array}$} & \multirow[t]{2}{*}{ Species included } & \multirow[t]{2}{*}{$N$} & \multirow[t]{2}{*}{ n Male } & \multirow[t]{2}{*}{$\begin{array}{l}n \\
\text { Female }\end{array}$} & \multirow[t]{2}{*}{ Percent } & \multicolumn{2}{|c|}{$\begin{array}{c}\text { Connectior } \\
\text { level }\end{array}$} \\
\hline & & & & & & $\mathbf{M}$ & SD \\
\hline \multirow[t]{4}{*}{ Great ape } & & 20 & 3 & 17 & 23.5 & 5.00 & 0.97 \\
\hline & Chimpanzee* & 1 & & & 1.2 & & \\
\hline & Gorilla & 5 & & & 5.9 & & \\
\hline & Orang-utan & 14 & & & 16.5 & & \\
\hline
\end{tabular}

This article is protected by copyright. All rights reserved. 


\begin{tabular}{|c|c|c|c|c|c|c|c|}
\hline \multirow[t]{2}{*}{$\begin{array}{l}\text { Large } \\
\text { Herbivore }\end{array}$} & & 20 & 3 & 17 & 23.5 & 4.60 & 1.54 \\
\hline & Elephant & 12 & & & 14.1 & & \\
\hline & Giraffe & 7 & & & 8.2 & & \\
\hline & Hippopotamus & 1 & & & 1.2 & & \\
\hline \multirow[t]{4}{*}{ Primate } & & 12 & 1 & 11 & 14.1 & 5.33 & 0.99 \\
\hline & Gibbon & 2 & & & 2.4 & & \\
\hline & Lemur & 6 & & & 7.1 & & \\
\hline & Monkey & 4 & & & 4.7 & & \\
\hline \multirow[t]{5}{*}{$\begin{array}{l}\text { Large } \\
\text { Carnivore }\end{array}$} & & 11 & 2 & 9 & 12.9 & 5.45 & 1.04 \\
\hline & African wild dog & 1 & & & 1.2 & & \\
\hline & Lion & 3 & & & 3.5 & & \\
\hline & Seal & 5 & & & 5.9 & & \\
\hline & Tiger & 2 & & & 2.4 & & \\
\hline \multirow[t]{4}{*}{$\begin{array}{l}\text { Small } \\
\text { carnivore }\end{array}$} & & 8 & 2 & 6 & 9.4 & 4.63 & 0.92 \\
\hline & Coati & 1 & & & 1.2 & & \\
\hline & Meerkat & 6 & & & 7.1 & & \\
\hline & Tasmanian devil & 1 & & & 1.2 & & \\
\hline
\end{tabular}




\begin{tabular}{|c|c|c|c|c|c|c|}
\hline & 4 & 3 & 1 & 4.7 & 4.25 & 1.50 \\
\hline Giant tortoise & 3 & & & 3.5 & & \\
\hline \multirow[t]{2}{*}{ Turtle } & 1 & & & 1.2 & & \\
\hline & 3 & 1 & 2 & 3.5 & 5.33 & 1.16 \\
\hline Penguin & 2 & & & 2.4 & & \\
\hline $\begin{array}{l}\text { Green-winged } \\
\text { macaw }\end{array}$ & 1 & & & 1.2 & & \\
\hline
\end{tabular}

Bird

macaw

Butterfly

30

3

$5.33 \quad 1.16$

(Species not

3 specified)

Small

herbivore

2

1

2.4

$\begin{array}{ll}5.00 & 0.00\end{array}$

Red panda

2

2.4

None

$2 \quad 2$

0

2.4

$2.50 \quad 2.12$

Total

$85 \quad 18$

67

100

*There are no chimpanzees on display at Melbourne Zoo

Table 3: Common themes and illustrative quotes describing zoo visitors' connection with an animal. When more than one theme is represented in a quote, a secondary theme is identified.

$\begin{array}{llll}\text { Theme } 1 & \text { Theme 2 } & \text { Animal type } & \text { Quote } \\ \text { Appreciation } & \text { Inspires } & \text { Elephant } & \text { View them with admiration. } \\ & \text { emotion } & & \begin{array}{l}\text { They bring a smile to your } \\ \text { face. Have empathy for } \\ \text { them. }\end{array}\end{array}$

This article is protected by copyright. All rights reserved. 


\begin{tabular}{|c|c|c|c|}
\hline Appreciation & $\begin{array}{l}\text { Inspires } \\
\text { emotions }\end{array}$ & Giraffe & $\begin{array}{l}\text { Giraffes have always been a } \\
\text { favorite animal of mine, } \\
\text { and seeing them brings up } \\
\text { memories of other times, } \\
\text { then to think of Africa, then } \\
\text { to think of their biology - a } \\
\text { lot really. }\end{array}$ \\
\hline Attribution & Interaction & Giraffe & $\begin{array}{l}\text { Empathy and a sense of } \\
\text { communication between } \\
\text { the animal and us humans. } \\
\text { To be able to sense a little } \\
\text { of what they experience in } \\
\text { some intangible form. }\end{array}$ \\
\hline Attribution & $\begin{array}{l}\text { Vicarious } \\
\text { connection }\end{array}$ & Orangutan & $\begin{array}{l}\text { I don't really know, but the } \\
\text { orangutan was depressed } \\
\text { on Friday and my 2-year old } \\
\text { niece tried to make it feel } \\
\text { better by drawing next to } \\
\text { it, she was very concerned } \\
\text { that it wasn't feeling well. }\end{array}$ \\
\hline Enjoyment & & Elephant & $\begin{array}{l}\text { I just love when the animals } \\
\text { are active and having fun in } \\
\text { their enclosure }\end{array}$ \\
\hline Enjoyment & Attribution & Lemur & $\begin{array}{l}\text { getting enjoyment and } \\
\text { feeling you 'know' that } \\
\text { animal }\end{array}$ \\
\hline $\begin{array}{l}\text { Inspires } \\
\text { emotion }\end{array}$ & Enjoyment & Coati & $\begin{array}{l}\text { Enjoyed observing them } \\
\text { and felt happy, calm just } \\
\text { standing there observing. }\end{array}$ \\
\hline $\begin{array}{l}\text { Inspires } \\
\text { emotion }\end{array}$ & - & Elephant & $\begin{array}{l}\text { My connection with the } \\
\text { elephants leaves me with a } \\
\text { feeling of sadness that the } \\
\text { species is endangered and } \\
\text { mistreated in so many } \\
\text { countries. But I am proud } \\
\text { that our zoo has their } \\
\text { program that protects } \\
\text { these majestic creatures }\end{array}$ \\
\hline Interaction & Empathy & Gorilla & $\begin{array}{l}\text { A sense of feeling that they } \\
\text { sense you and your feelings } \\
\text { and show a little in return. }\end{array}$ \\
\hline
\end{tabular}

This article is protected by copyright. All rights reserved. 


\begin{tabular}{|c|c|c|c|}
\hline Interaction & $\begin{array}{l}\text { Inspires } \\
\text { emotions }\end{array}$ & Lion & $\begin{array}{l}\text { I look in to its eyes and feel } \\
\text { that I am communicating. I } \\
\text { felt an emotional response } \\
\text { from the interaction. }\end{array}$ \\
\hline Interaction & $\begin{array}{l}\text { Human } \\
\text { characteristics }\end{array}$ & Orangutan & $\begin{array}{l}\text { The animal is looking at } \\
\text { us/watching us. Showing } \\
\text { behaviors we can relate to } \\
\text { (parenting, playing). Seems } \\
\text { to acknowledge you are } \\
\text { there by 'showing' you } \\
\text { what it can do, what } \\
\text { sounds it makes. The } \\
\text { animal moves closer to you. } \\
\text { Sometimes the connection } \\
\text { is just an enjoyment of } \\
\text { seeing the animal closer } \\
\text { than we have before. }\end{array}$ \\
\hline Learning & Proximity & Giraffe & $\begin{array}{l}\text { I feel we learnt a lot during } \\
\text { the talk and it was amazing } \\
\text { being so close to such a } \\
\text { majestic animal. }\end{array}$ \\
\hline Learning & - & Lemur & $\begin{array}{l}\text { An interest in the life of } \\
\text { that animal. }\end{array}$ \\
\hline Natural world & Appreciation & Butterfly & $\begin{array}{l}\text { Such a pure experience. } \\
\text { There is purity in the animal } \\
\text { kingdom, a sense of no } \\
\text { judgement just an equal } \\
\text { field of being inquisitive } \\
\text { about each other. }\end{array}$ \\
\hline Natural world & Protection & Tiger & $\begin{array}{l}\text { A connection with an } \\
\text { animal means to me that I } \\
\text { feel a type of kinship with it } \\
\text { or it helps me to see that } \\
\text { there are many other } \\
\text { species on earth that we } \\
\text { should be taking into } \\
\text { consideration when we } \\
\text { make decisions regarding } \\
\text { resource use. }\end{array}$ \\
\hline $\begin{array}{l}\text { Observation } \\
\text { without }\end{array}$ & - & Hippopotamus & $\begin{array}{l}\text { I wasn't expecting any } \\
\text { connection with the }\end{array}$ \\
\hline
\end{tabular}

This article is protected by copyright. All rights reserved. 
interaction

Observation Learning Orangutan
without
interaction

Pet Inspires Lion

characteristics emotions

Pet

characteristics

Protection

Turtle animals so didn't look for one. I also don't feel that I am entitled to any response from the animals.

A connection with an animal means to me that I am able to view the animal without it seemingly being disturbed by my presence. Included in this is that I appreciate the animal for its biology and evolutionary history. I therefore enjoy learning about the biology of many animal species. While I am happy to physically interact with domestic pets that approach me, I do not find a similar level of need to physically interact with non-pet exotic species. I have been fortunate to hold a young orangutan whilst holidaying in Bali, and while this was quite a positive experience, I don't feel this is important to do every time I am at a zoo.

I felt a connection with the lion in terms of its links with my passion for cats (domestic and wild) and its resemblance to my own cat's behaviors. In addition, it took me back to my trip to Africa, a treasured trip.

it reminded me with my pet (turtle) that I had 20yrs ago before I moved to Australia

Green winged macaw

Sense of protection over this bird species as Amazon is slowly 'destroyed' by human so called

This article is protected by copyright. All rights reserved. 


\begin{tabular}{|c|c|c|c|}
\hline & & & 'development' \\
\hline Protection & - & None reported & $\begin{array}{l}\text { Caring and making the } \\
\text { world a safer place for } \\
\text { wildlife }\end{array}$ \\
\hline Proximity & $\begin{array}{l}\text { Inspires } \\
\text { emotions }\end{array}$ & Lemur & $\begin{array}{l}\text { From the close encounter } \\
\text { enclosure, it was amazing } \\
\text { to get so up close with the } \\
\text { lemurs and almost so close } \\
\text { we could touch them! It } \\
\text { was like we were in } \\
\text { another world }\end{array}$ \\
\hline Proximity & Interaction & Orangutan & $\begin{array}{l}\text { When you are able to see } \\
\text { the animal at close } \\
\text { proximity; its every detail. } \\
\text { Often it will look into your } \\
\text { eyes from this close } \\
\text { proximity, or interact with } \\
\text { you in some way providing } \\
\text { this sense of connection; } \\
\text { i.e., the baby orangutan } \\
\text { would dance and come up } \\
\text { for a look at people for } \\
\text { curiosity. Also, being able } \\
\text { to see what the animal may } \\
\text { do in its natural habitat; } \\
\text { i.e., swinging from branch } \\
\text { to branch, playfulness etc. }\end{array}$ \\
\hline $\begin{array}{l}\text { Trait } \\
\text { recognition }\end{array}$ & - & Orangutan & $\begin{array}{l}\text { Orangutan are very } \\
\text { intelligent animals and it } \\
\text { was fascinating to watch } \\
\text { one putting a stick through } \\
\text { a grid in their enclosure. }\end{array}$ \\
\hline $\begin{array}{l}\text { Vicarious } \\
\text { connection }\end{array}$ & Interaction & Butterfly & $\begin{array}{l}\text { I enjoy the experience of } \\
\text { the butterflies landing on } \\
\text { me and observing my son } \\
\text { patiently hold his arm and } \\
\text { wait for them to land on } \\
\text { him and the excitement he } \\
\text { experiences when this } \\
\text { happens. Hence, it is a } \\
\text { sensory experience we } \\
\text { enjoy in the animal's own } \\
\text { environment. }\end{array}$ \\
\hline
\end{tabular}

This article is protected by copyright. All rights reserved. 


\begin{tabular}{|c|c|c|c|}
\hline $\begin{array}{l}\text { Vicarious } \\
\text { connection }\end{array}$ & Enjoyment & Elephant & $\begin{array}{l}\text { Elephants are my 3-year } \\
\text { old's favorite animal and } \\
\text { the strong connection was } \\
\text { felt via his enthusiasm and } \\
\text { excitement of seeing the } \\
\text { animals - both roaming in } \\
\text { the paddocks, being fed, } \\
\text { bathed, checked and } \\
\text { trained. We all loved the } \\
\text { first-hand experience of } \\
\text { seeing all these aspects of } \\
\text { the elephants' daily life. }\end{array}$ \\
\hline Welfare & Proximity & Chimpanzee & $\begin{array}{l}\text { Being able to get up close } \\
\text { and feeling like it is happy } \\
\text { and in a good-sized } \\
\text { enclosure so it is able to get } \\
\text { away from seeing people if } \\
\text { it needed some space }\end{array}$ \\
\hline Welfare & $\begin{array}{l}\text { Human } \\
\text { characteristics }\end{array}$ & Gibbon & $\begin{array}{l}\text { Just a bit older \& I wonder } \\
\text { what kind of life they } \\
\text { have/are having - } \\
\text { questioned captivity. } \\
\text { Introduced my new baby as } \\
\text { if they'd care \& like babies }\end{array}$ \\
\hline $\begin{array}{l}\text { Don't } \\
\text { understand }\end{array}$ & - & Elephant & $\begin{array}{l}\text { I am not really sure I } \\
\text { understand this question }\end{array}$ \\
\hline $\begin{array}{l}\text { Don't } \\
\text { understand }\end{array}$ & - & None reported & I don't understand this \\
\hline
\end{tabular}

Table 4: Pearson's $r$-values correlating various items with overall connection level with the animal. Only significant results are reported here.

Item

Species-specific conservation caring ${ }^{1}$

I feel a sense of calm when I watch wildlife

\section{Overall} connection level

$0.44^{* * *}$

$0.38 * * *$

This article is protected by copyright. All rights reserved. 
I will endorse public policy that severely restricts future growth and development in order to protect wildlife

Amount willing to donate to help conserve this species as a monthly donation

Perceived welfare in enclosure ${ }^{1}$

Even when they are more expensive or harder to find, I will buy $0.25^{*}$ groceries and products that support wildlife conservation

Amount willing to donate to help conserve this species as a one- $0.24 * *$ off donation

${ }^{1}$ Indicates composite variables; see Table 1 for a description

*Relationship is significant at $p<0.05 * *$ Relationship is significant at $p<0.01$. $* * *$ Relationship is significant at $p<0.001$. 


\section{University Library}

\section{- M M I N E R VA A gateway to Melbourne's research publications}

Minerva Access is the Institutional Repository of The University of Melbourne

Author/s:

Howell, TJ;McLeod, EM;Coleman, GJ

Title:

When zoo visitors "connect" with a zoo animal, what does that mean?

Date:

2019-08-08

Citation:

Howell, T. J., McLeod, E. M. \& Coleman, G. J. (2019). When zoo visitors "connect" with a zoo animal, what does that mean?. ZOO BIOLOGY, 38 (6), pp.461-470. https://doi.org/10.1002/ zoo.21509.

Persistent Link:

http://hdl.handle.net/11343/286258 